\title{
SYSTEM OF FUZZY AUTOMATIC CONTROL OF COAL MASSIF CUTTING BY A SHEARER DRUM
}

\author{
${ }^{1}$ D nipro U niversity of Technology \\ 19 D mytra Yavornytskoho Ave., D nipro 49005, U kraine; e-mail: bublikov.a.v@ nmu.one, \\ Papaika.Yu.A@nmu.one \\ 2Institute of Technical Mechanics \\ of the National Academy of Sciences of U kraine and the State Space Agency of U kraine \\ 15 Leshko-Popel St., Dnipro 49005, Ukraine; e-mail: np-2006@ ukr.net
}

\begin{abstract}
Up to now, automatic control of the shearer speed has been performed to keep the actual speed at an operator-specified level or to keep the actual power at a stable level without overheating or overturning. However, the problem of control of coal seam cutting by the upper drum of a shearer in the case of a variable angle of drum - coal seam contact has yet to be studied.

The aim of this work is to develop a method for synthesizing a system of fuzzy automatic control of coal massif cutting by a shearer drum based on an information criterion for the power efficiency of coal cutting with cutters.

In this work, based on an information criterion for the power efficiency of coal cutting with cutters, a fuzzy inference algorithm is constructed for a system of automatic control of coal massif cutting by a shearer drum. In doing so, the parameters of the output linguistic variable term membership functions of the system and fuzzy operations are determined according to the recommendations of the classical Mamdani fuzzy inference algorithm using substantiated fuzzy production rules.

The fuzzy inference algorithm constructed in this work is tested for efficiency based on the fraction of effective control actions generated by the fuzzy automatic control system. Using simulation, the efficiency of drum rotation speed control with the use of the proposed fuzzy inference algorithm is compared with that with the use of an uncontrolled shearer cutting drive.

The study of the generation of control actions involving the upper shearer drum rotation speed showed that effective control actions were generated in the overwhelming majority of cases (about 93\%).

The proposed method forms a theoretical basis for the solution of the important scientific and practical problem of upper shearer drum rotation speed control automation with the aim to reduce specific power consumption and the amount of chips.
\end{abstract}

Keywords shearer, system of fuzzy automatic control, drum, rotation speed.

1. Tkachev V. V., Bublikov A. V. Use of Simulation in the Study of a Shearer Automatic Control System. Dnipropetrovsk: National Mining University, 2015. 182 pp. (in Russian)

2.Gorbatov P. A., Kosarev V. V., Stadnik N. I. Conceptual characteristics of complex mining machine as mehatronic systems. Naukovi Pratsi DonNTU. 2006. . 2006. No. 104. Pp. 53-61/ (n Russian). .

3. Zhang Wei, Zhang Dongsheng, Wang Hongzhi, Cheng Jixin.

Comprehensive technical support for high-quality anthracite production: a case study in the Xinqiao coal mine, Yongxia mining area, China. Minerals. 2015. No. 5. Pp. 919-935.

https://doi.org/10.3390/min5040533

4. Sysoev N. I., Kozhevnikov A. S. Algorithm and technical implementation of mechatronic control of shearer operating parameters. . Naukovi Pratsi

DonNTU. Seria Hirnycho-Elekromekhanichna. 2010. No. 18. Pp. 249-255. (in Russian). 
5. Stadnik N. I., Eremin A. V., Tarash E. V. Optimization of the operation of a shearer with a variable-frequency cutting drive. Geo-Technical Mechanics. 2015. No. 122. Pp. 238-252. (in Russian).

6. Panikhidnikov S. A., Novoselov S. V., Kulinkovich A. V. Evaluation of a man-machine (operator-shearer) subsystem within a production face of a coal mine as one of the methodological elements of coal mining safety evaluation. Mining Informational and Analytical Bulletin. 2018. No. 10. Pp. 227-233. (in Russian).

https://doi.org/10.25018/0236-1493-2018-10-0-227-233

7. Bublikov A., Tkachov V. Automation of the control process of the mining machines based on fuzzy logic. Naukovyi Visnyk Natsionalnoho Hirnychoho Universytetu. 2019. No. 3. p. 112-118.

https://doi.org/10.29202/nvngu/2019-3/19

8. Bublikov A. V., Pryadko N. S., Ternova K. V., Sosnin K. V. Identification of a mode of coal massif cutting by a shearer drum. System Technologies. 2021.

No. 5 (136). Pp. 144-158. (in Ukrainian). 